\title{
SANGHIANG TARAJE, TINGGALAN TRADISI MEGALITIK DI GUNUNG TAMPOMAS
}

\section{Lucas Partanda Koestoro}

Keywords: archaeology; megalithic; dolmen; folklore; menhir

\section{How to Cite:}

Koestoro, L. P. (1987). SANGHIANG TARAJE, TINGGALAN TRADISI MEGALITIK DI GUNUNG TAMPOMAS. Berkala Arkeologi, 8(2), 36-46. https://doi.org/10.30883/jba.v8i2.491

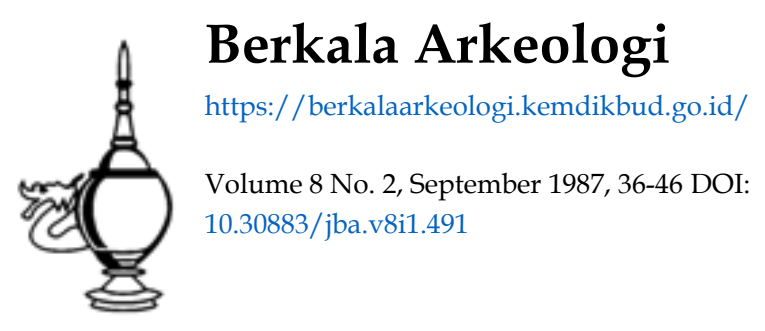




\section{SANGHIANG TARAJE TINGGALAN TRADISI MEGALITIK DI GUNUNG TAMPOMAS*}

Lucas Pcrtanda Koestoro

1. Ketika kekacauan melanda Pakwan Pajajaran akibat adanya gempuran pasukan Banten yang sedang mengibarkan panji-panji Islam, Prabu Siliwangi sebagai penguasa Sunda kala itu segera mendatangi salah satu vasalnya yakni Sumedang Larang. Empat orang patihnya, di antaranya Sayang Hawu atau lebih dikenal dengan sebutan Embah Jayaperkosa, diperintahkan untuk menyerahkan sebuah pusaka kraton berupa.mahkota emas kepada Prabu Geusan Ulun, penguasa Sumedang Larang. Kejadian yang dapat diartikan sebagai penyerahan tahta kerajaan Sunda itu diikuti dengan keberangkatan Prabu Siliwangi menuju puncak gunung Tampomas.

Dalam kekalutannya setelah sadar bahwa upaya untuk kembali mempertahankan kerajaannya tidak mungkin dilakukan, Prabu Siliwangi menekuni semedi di puncak gunung Tampomas itu. Di sanalah beliau ngahiang, hilang secara gaib mengikuti ajaran agama yang dianutnya. Sayang Hawu, patih setia yang ingin mengikuti jejak. nya justru diperintahkan untuk mengabdi kepada Prabu Geusan Ulun. Belakangan Sayang Hawu berperan sebagai patih utama Prabu Geusan Ulun dan setelah keduanya meninggal dimakamkan pada puncak sebuah bukit di sebelah selatan gunung Tampomas. Tempat tersebut sekarang dikenal dengan nama Dayeuh Luhur. Karena kalah tua dibandingkan dengan Sayang Hawu, keletakan makam Prabu Geusan Ulun berada pada tempat yang lebih rendah daripada makam Sayang Hawu.

- Peninjauan ke lokasi dilaksanakan pada bulan Januari 1987 bersama Staf Laboratorium Paleoekologi Radiometri, Bandung, yaitu Sdr. Rochendi, Y. Hardi Kusmana dan D. Saripudin. Penyelesaian gambar-gambar dibantu oleh Sdr. Anwar Sanusi. 
Hal tersebut adalah sekelumit cerita rakyat tentang keberadaan Sanghiang Taraje di puncak gunung Tampomas dalam kaitannya dengan kisah Prabu Siliwangi, tokoh yang dianggap sebagai pemegang tahta kerajaan Sunda dahulu. Sanghiang Taraje adalah sebutan untuk puncak gunung Tampomas berikut tinggalan yang terdapat di areal sekitarnya. Menurut keterangan yang diberikan oleh Nunu Suryana, Penilik Kebudayaan Depdikbud kecamatan Buahdua, mengutip pernyataan Gunawan Suria DN, Camat Buahdua, bagian gunung itu masuk dalam wilayah administrasi kecamatan Buahdua, kabupaten Sumedang, Jawa Barat. Cara termudah untuk mencapainya adalah mengikuti jalan setapak yang berawal dari desa $\mathrm{Ci}$ beureum Kulon di wilayah kecamatan Cimalaka. Jarak tersebut dapat ditempuh dalam waktu sekitar empat jam.

II.1. Dalam bahasa Sunda, taraje berarti tangga. Tinggalan yang berada di puncak gunung Tampomas itu memang memiliki tangga berupa susunan batu andesit. Secara keseluruhan kekunaan Sang. hiang Taraje merupakan bangunan berundak dengan tiga teras atau halaman. Karya cipta arsitektur yang terletak sekitar tiga ratus meter di sebelah utara puncak tertinggi gunung Tampomas itu memiliki arah hadap utara - selatan, yaitu pada ketinggian sekitar 1600 meter DPAL. Berawal dari bagian selatan,masing-masing halaman dihubungkan dengan pintu beranak tangga batu, pembagian ha laman bangunan berundak ini bersifat memusat ke belakang. Luas keseluruhannya kurang-lebih 25 meter $\times 18$ meter. Bahan pem bentuknya adalah batuan andesit yang tampaknya belum atau tidak mengalami penggarapan. Kalaupun ada, pengerjaan yang dimaksud terbatas hanya pada beberapa batuan komponen pembentuk bagian pintu.

Pengamatan terhadap struktur bangunan berundak ini memper lihatkan teknologi struktur yang sederhana. Sistem yang digunakan itu dikenal sebagai sistem konstruksi massa, yakni dengan hanya menumpuk komponen/material batuan yang dipakai sehingga tercipta suatu massa yang homogen. Selanjutnya untuk mendapatkan 
dinding vang rapi dilakukan pengaturan letak batuan di bagian tep struktur dinding tersebut. Hal ini tampak terutama pada struktur di halaman ketiga, bagian yang paling utuh dari keseluruhan bangunan berundak tersebut.

\section{II.2 Halaman pertama}

Bagian yang masih tersisa dari halaman yang keletakannya paling rendah ini adalah struktur batuan penahan tanah di sisi Selatan dengan anak tangga di bagian tengahnya. Sisa struktur batuan yang juga pembentuk ruang itu sekitar 12 meter, memanjang dengan arah barat - timur. Sebagian besar struktur batuan di sisi Timur dan Barat telah hilang. Ruang yang terbentuk sebagai halaman pertama bangunan berundak ini memiliki ukuran 14 meter $\times 6$ meter.

Di halaman ini, di kedua sisi pintu masuk beranak tangga batu terdapat arca menhir (?). Ada kesan bahwa benda tersebut dimaksudkan sebagai penjaga pintu masuk. Arca menhir yang berada di sebelah barat keadaannya masih utuh, berdiri tegak dengan tinggi sekitar $110 \mathrm{~cm}$, lebar bagian bawah $35 \mathrm{~cm}$ dan bagian atas $18,5 \mathrm{~cm}$. Bagian atas batuan andesit itu berbentuk muka manusia dengan mata, hidung, dan mulut yang digambarkan secara sederhana. Anggota badan lainnya tidak digambarkan. Sekilas benda yang berbangunsilindrik itu memberi kesan penggambaran alat kelamin laki-laki, dan hal ini pula yang menyebabkan sebagian masyarakat menyebutnya dengan batu kontol. Di sebelah timur, pada sekitar $170 \mathrm{~cm}$ dari arca menhir yang masih utuh tadi, terdapat bagian bawah arca yang tampaknya sejenis dengan yang terdahulu. Ukuran bagian bawahnya sama, tetapi tingginya hanya tersisa $35 \mathrm{~cm}$ saja.

\section{II.3 Halaman kedua}

Di halaman inipun sebagian batu pembentuk struktur sisi barat dan timur telah hilang, karena berjatuhan ke jurang di bawahnya. Secara keseluruhan masih dapat diketahui ukuran ruang yang terbentuk di halaman ini, yakni 14,1 meter $\times 6.2$ meter Seperti 
halnya dengan keadaan di halaman pertama. bagian tengah ha laman kedua ini dipenuhi dengan tumbuh-tumbuhan yang cukup rapat. Tebal struktur penahan tanahnya, yakni struktur sisı selatan, adalah $120 \mathrm{~cm}$. Di sebelah/barat pintu masuk selebar $70 \mathrm{~cm}$ dijumpai pula pecahan batuan yang sejenis dengan arca penjaga pintu masuk halaman pertama. Lebar bagian bawah adalah $30 \mathrm{~cm}$ sedangkan tingginya hanya tersisa $30 \mathrm{~cm}$.

\section{II.4 Halaman ketiga}

Halaman ini lebih bersih daripada halaman-halaman sebelum. nya. Pada waktu-waktu tertentu cukup banyak peziarah yang ber kunjung dan menginap di tempat ini. Salah satu penyebabnya mungkin karena halaman tersebut dikelilingi struktur batu setinggi $100-130 \mathrm{~cm}$ dengan ketebalan antara $90 \mathrm{~cm}$ sampai $190 \mathrm{~cm}$, sehingga mampu menahan hembusan angin yang cukup keras di daerah tersebut.

Luas halaman utama bangunan berundak tersebut adalah 14,6 meter $\times 6,7$ meter. Di bagian tengah terdapat dua batur berbentuk empat persegi panjang, yang masing-masing berukuran 3,8 meter $X$ 3,1 meter dan 3,4 meter $\times 2,3$ meter. Pada batur pertama yang berada di sebelah timur dijumpai dua buah makam (?) yang masingmasing ditandaı dengan 'nisan' berupa batu tatapakan (= umpak) serta batu ajeg (= batu yang didirikan tegak). Di batur lainnya, makam yang ada ditandai juga dengan batu tatapakan. Ukuran batu tatapakan itu adalah $33 \mathrm{~cm} \times 35 \mathrm{~cm}$ dengan tinggi sekitar $25 \mathrm{~cm}$. sedangkan batu ajeg berukuran $16 \mathrm{~cm} \times 22 \mathrm{~cm}$ dengan tinggi $53 \mathrm{~cm}$. Ketiga makam tersebut berarah hadap utara - selatan.

Di sudut Tenggara halaman utama bangunan berundak ini ter dapat sebuah batu datar dengan tonjolan di salah satu ujungnya. Benda yang dikenal dengan sebutan batu kasur itu berukuran 2 meter $\times 1,4$ meter dengan tebal antara $30 \mathrm{~cm}$ hingga $90 \mathrm{~cm}$ dan diletakkan dengan arah barat - timur Oleh sebagian masya. rakat batu kasur ini dikatakan sebagai tilas pangcalikan (= bekas tempat duduk) Prabu Siliwangi ketika menekunı semedinya sebelum 
ngahiang ( $=$ moksa). Oleh karena itu didekatnya masih dapat dilihat urut parukuyan ( $=$ sisa pembakaran kemenyan dan bungabunga tabur).

III.1 Berbicara tentang bangunan berundak Sanghiang Taraje tentunya tidak lepas dari suatu pemahaman bahwa arsitektur dalam bentuk purbanya adalah sesuatu yang dibangun manusia dalam kehidupannya waktu itu untuk dijadikan sarana perlindungan demi kepentingan badan maupun keselamatan jiwanya (Djauhari Sumintardja, 1978 : 3). Hal ini tentunya tidak berbeda jauh dengan pengertian arsitektur masa kini yang berarti seni merencanakan bangunan bagi manusia yang bernaluri mencari keamanan dan kenyamanan diri demi kesejahteraan jiwa dan raganya, sekaligus memenuhi kepuasan diri dalam mencipta suatu keindahan. Sebagai hasil cipta karya suatu kebudayaan, wujud arsitektur dipengaruhi oleh beberapa unsur. Unsur-unsur tersebut adalah geografis, kemasyarakatan, agama, maupun falsafah kepercayaan sertalatar belakang sejarah, yang nantinya akan mempengaruhi bentuk serta gaya bangunan yang dihasilkan (Hasan Shadily (Ed.), 1980: 272). Dengan kata lain terciptanya suatu bangunan merupakan bagian kerja manusia untuk meluruskan keadaan di sekitarnya dengan pandangan-pandangan hidupnya (V.R. Van Romondt, tanpa tahun : 3). Dengan demikian suatu karya arsitektur merupakan ekspressi dari suatu bentuk kehidupan (Saieh Amirudin, 1978 : 15).

Tinggalan Sanghiang Taraje yang merupakan bangunan berundak tentunya tidak sekedar dibuat tanpa memiliki arti serta fungsi tertentu bagi kelompok masyarakat pembuatnya. Setidak-tidaknya, dengan menghubungkannya pada cerita rakyat yang masi h hidup saat ini, karya cipta tersebut pernah digunakan atau difungsikan oleh seorang tokoh yang besar pamornya dalam masyarakat Sunda. Apalagi bila dikaitkan dengan banyaknya temuan sejenis di Jawa Barat, seperti bangunan berundak di Gunung Padang, Cianjur (D.D. Bintarti, 1981: 31) dan Pangguyangan, Sukabumi (Haris Sukendar dkk., 1977: 6) yang oleh para ahli telah disepakati sebagai tempat pe- 
mujaan terhadap nenek moyang. Pada garis besarnya tentu tidak berlebihan bila disebutkan bahwa tinggalan yang berada di puncak gunung Tamponas itu juga tumbuh dari suasana keagamaan dan sekaligus memiliki suatu fungsi dalam kehidupan keagamaan tadi. III.2. Penelitian-penelitian yang intensif tentang bangunan berundak antara lain menghasilkan kesepakatan tentang telah dikenalnya pemakaian bentuk bangunan berundak sejak berlangsungnya tradisi megalitik pada akhir masa neolitik dan permulaan masa perundagian. Hal yang mendasari pembangunannya adalah kepercayaan akan adanya pengaruh yang kuat dari yang telah mati terhadap kesejahteraan masyarakat dan kesuburan tanaman. Oleh karena itu perlu dilakukan pemujaan kepada roh nenek moyang yang dianggap sebagai pelindung keturunannya yang masih hidup di dunia.

Berkaitan dengan kepercayaan tersebut, pada masyarakat kala itu juga terdapat anggapan bahwa tempat yang tinggi keletakannya merupakan tempat yang keramat dan dihormati. Anggapan yang demikian menyebabkan banyak ditemukannya bangunan berundak di puncak-puncak gunung. Masih berhubungan dengan itu, pada bangunan-bangunan berundak dari masa berkembangnya tradisi megalitik sering dijumpai adanya penggambaran tokoh manusia dalam bentuk yang sederhana. Kadang-kadang penggambarannya tidak utuh, misalnya bagian muka atau alat kelaminnya saja.

Dalam kepercayaan masyarakat yang tumbul pàda masa itu. tubuh manusia serta bagian-bagian tertentu dari tubuh manusia seperti muka, mulut, dan alat kelamin dianggap memiliki kekuatan gaib. Oleh karena itu penggambarannya ditujukan untuk memperoleh kekuatan gaib dari tokoh yang dimaksud. Kekuatan gaib itu antara lain adalah kekuatan untuk menolak bala.

IV. Sekiranya Prabu Siliwangi sebagai penguasa kerajaan Sunda pada abad 16 itu benar-benar tokoh historis, dan cerita rakyat tentang Sanghiang Taraje sebagai tempat ngahiang-nya bukan sekedar cerita rekaan, kemungkinan Prabu Siliwangi memanfaatkan ba. ngunan berundak yang sebelumnya memang telah berdiri di tempat 
itu. Kehadiran bangunan berundak itu lebih dimungkinkan akibat aktifitas masyarakat Sunda kuna yang dahulu hidup sebagai masyarakat agraris. Jadi bangunan tersebut tidak semata-mata dibangun untuk keperluan Prabu Siliwangi, melainkan ujud dari adanya keinginan untuk tetap menjalin hubungan dengan nenek moyangnya, memohon perlindungan bagi keselamatan dan kesejahteraan hidupnya, kesuburan atas tanamannya, serta mengucapkan syukur atas keberhasilan panen yang telah dinikmatinya. Kalaupun kemudian timbul cerita seperti yang telah disebutkan di muka, hal itu tampaknya merupakan kecenderungan untuk tetap mengamalkan kebiasaan lama pada saat hadirnya paham atau ajaran agama baru di tanah Sunda. Bagi kepentingan politis tokoh tertentu, kecenderungan untuk bersikap seperti itu pada masyarakat justru besar manfaatnya bagi usaha legitimasi tokoh tadi.

Menarik untuk dicatat bahwa hingga saat ini masih sering terdapat sejumlah petani yang beziarah ke bangunan berundak tersebut sehabis melaksanakan panen dengan membawa sasajen (= sesaji) berupa hasil bumi yang dipanen (padi, dan sebagainya), duwegan (= kelapa muda), surutu (= cerutu), cai kopi pait (= air kopi pahit), endog hayam (= telur ayam), uang logam, kembang tujuh rupa, serta kemenyan yang dibakar di bagian tengah batur barat halaman utama. Mereka kembali dengan harapan akan memperoleh hasil panen yang lebih baik pada musim tanam berikutnya. Sebelum sampai ke lokasi Sanghiang Taraje, mereka juga meletakkan sesaji di sebuah ceruk batu di sebelah timur puncak gunung Tampomas, yang berjarak kurang lebih satu jam perjalanan kaki. 


\section{KEPUSTAKAAN}

D.D. Bint arti, 1981. "Punden Berundak Di Gunung Padang, Jawa Barat", Amerta. No. 4, Jakarta, Proyek Penelitian Purbakala, hat 28- 37.

Djauhari Sumint ardja, 1978. Kompendium Sejaroh Arsitektur I, Bandung, Yayasan Lembaga Penyelidikan Masalah Bangunan.

Haris Sukendar, dkk., 1977. "Penelitian Prasejarah Di Daerah Jampangkulon Dan Sekit arnya (Jawa Barat)", Berita Penelitian Arkeologi, No. 10, Jakarta, Proyek Pengembangan Media Kebudayaan.

Haris Sukendar, 1981 / 1982. 'Tradisi Megalitik Di Indonesia", Analisis Kebudayaan, Th. II, No. 1, ,Jakarta, Depdikbud, hlm. 79-86.

Hasan Shadily, Ed., 1980. Ensiklopedi Indonesia I. Jakarta, Ichtiar Baru - Van Hoeve.

Heekeren, HR. Van, 1955. Penghidupan Dalam Zaman Praseiarah Di Indonesia. terjemahan Moh. Amir Sut aarga, Jakarta, P.T. Soeroengan.

Hendraningsih, dkk., 1982. Peran, Kesan Dan Pesan Bentuk-Bentuk Arsitektur, Jakarta, Djambatan.

Hoop, A.N.J. Th. a Th. Van Der, 1949. Indonesische Siermotieven. Bat avia, Koninklijk Bat aviaasch Genootsct0p V/an Kunsicn En Wetenschappen.

RP. Soejono, Ed., 1977. Sejarah Nasional Indonesia I, Jakarta, Balai Pustaka. 


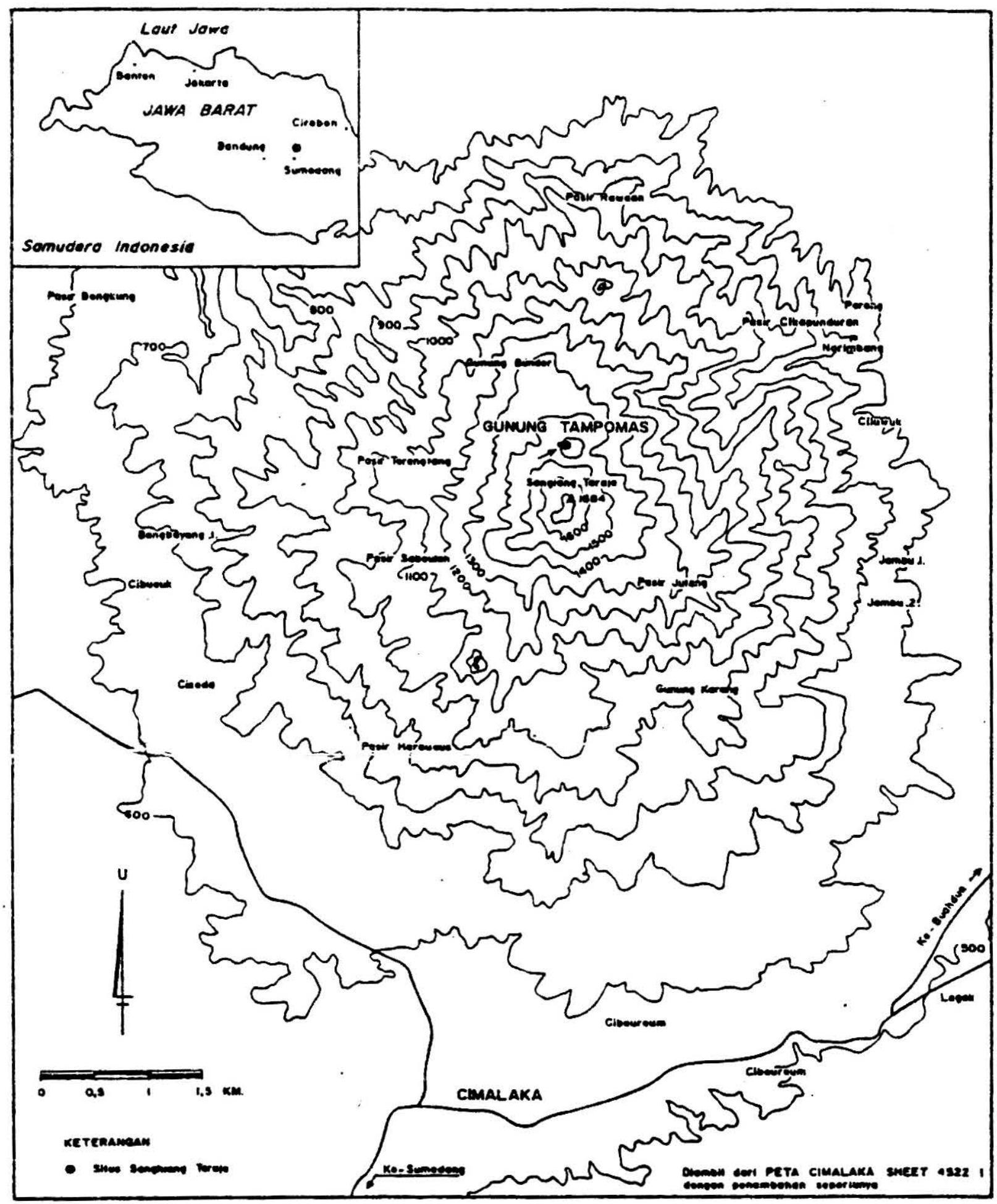

Peta Keletakan Situs Sanghiang Taraje, Gunung Tampomas. 


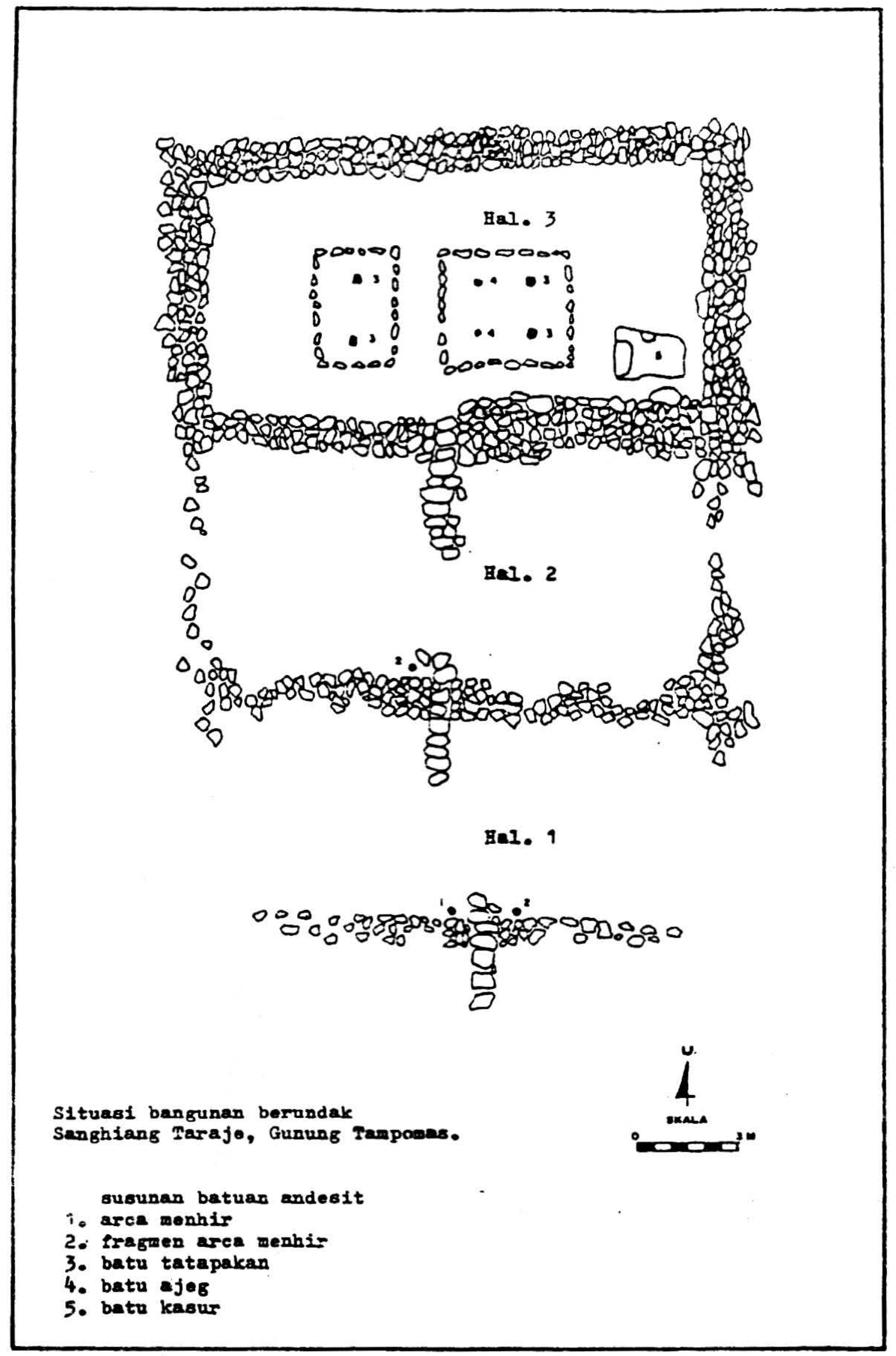




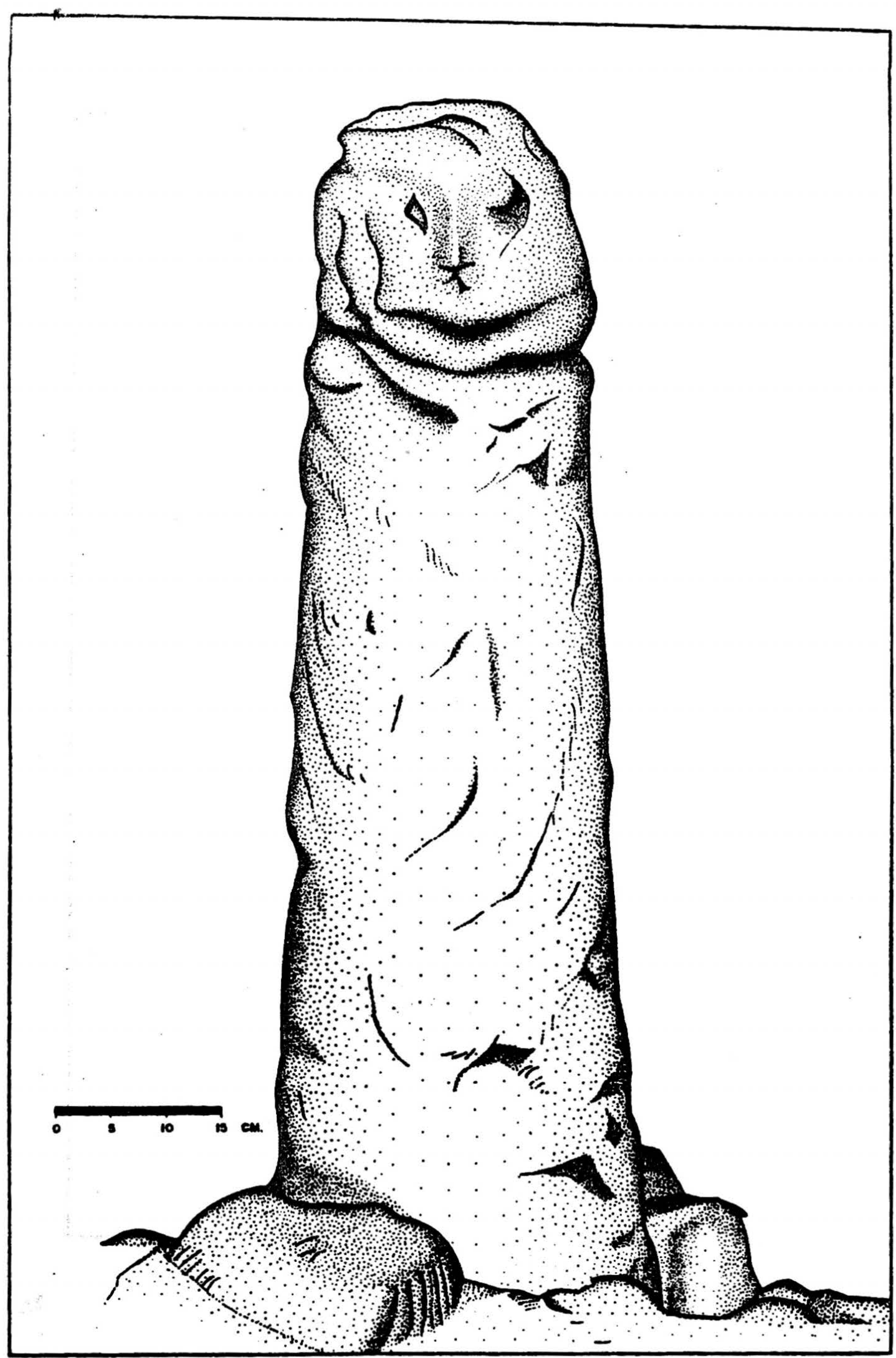

Arca menhir di Sanghiang Taraje. Gunung Tampomas. 